DOI https://doi.org/10.30525/978-9934-26-073-5-1-14

\title{
VIRTUAL LABORATORY «MULTIMEDIA DICTIONARY OF INFOMEDIA LITERACY»
}

\author{
Semenog O. M. \\ Doctor of Pedagogical Sciences, Professor, \\ Head of the Ukrainian Language and Literature Department \\ of the Faculty of Foreign and Slavic Philology \\ Sumy State Pedagogical University named after A. S. Makarenko \\ Sumy, Ukraine \\ Nadutenko M. V. \\ Candidate of Philological Sciences, \\ Senior researcher at the Linguistics Department \\ Ukrainian Lingua-Information Fund \\ of the National Academy of Sciences of Ukraine \\ Kyiv, Ukraine \\ Nadutenko M. V. \\ Candidate of Technical Sciences, \\ Head of the Information Department, \\ Ukrainian Lingua-Information Fund \\ of the National Academy of Sciences of Ukraine \\ Kyiv, Ukraine
}

The concept of «infomedia literacy» is increasingly entering to the scientific space. Researchers focus on such components of the concept as critical thinking, the ability to critically evaluate media texts and detect manipulative media content, to analyze and evaluate media messages, to distinguish facts from judgments, to detect fakes; information ethics and tolerance (ability to ask questions, explain the tokens «hostility in the media», communicate ethically) [1]. The need to study in more detail and use the terminology of infomedia literacy necessitates the creation of a computer multilingual instrumental system of terminology, which experts describe as a special implementation of the so-called virtual lexicographic laboratory [2]. The main product of the work will be a terminological multimedia dictionary on information literacy. According to its content and structure, the dictionary takes into account the specifics of the linguistic approach to text analysis in the media. This dictionary is an attempt to systematize the terminology of media 62 
linguistics, also takes into account the IREX methodology, which focuses on the formation of user competencies in information literacy.

The Virtual Laboratory «Multimedia Dictionary of Infomedia Literacy» creates an appropriate linguistic and technical environment focused on ensuring professional interaction of specialists in the field of media remotely. As the analysis shows, digital lexicography has become quite widespread in European practice and for the most languages of the world, a functionally complete digital lexicographic space has been formed. In Ukraine, the declared industry is still under development. Only the Ukrainian Lingua-Information Fund of the National Academy of Sciences of Ukraine has experience in creating and commercially producing new types of electronic dictionaries. Specialists of the academic institution study the theoretical and scientifictechnical principles of development of modern high-performance computer tools for the formation of lexicographic systems. The result is the effectiveness of the implemented tools in the form of virtual lexicographic laboratories. Within the article we will outline the purpose, tasks, principles of work of the virtual lexicographic laboratory «Multimedia Dictionary of Infomedia Literacy». The purpose of the virtual lexicographic laboratory is to introduce the latest information tools for virtual interaction in the educational and lexicographic processes of media education and to create a new type of dictionary based on modern linguistic technologies and theories. Compiling the dictionary is aimed to perform a number of tasks: to create an experimental system of virtual professional interaction, which uses modern linguistic technologies; to create an innovative information and reference resource containing information about the elements of the ontology of the subject area "media" (classes of terms, their definitions and multimedia), which is an open system, can be updated in real time and filled with new features; to provide basic information about the key terms of the information literacy to a wide range of users; to use of the dictionary as a practical simulator for students and pupils. Target audience of the dictionary: students, specialists in the field of communication with media, journalists, teachers, academics, a wide range of users who are professionally interested in the media sphere. The project is based on the ideas and provisions of the PISA 2018 (Program for International Student Assessment) research in terms of reading competence. The Concept of Media Education in Ukraine (2016), the Law of Ukraine «On ensuring the functioning of the Ukrainian language as the state language» (2019). The importance of the project is proved by the results of the IREX grant program «Educational Research Center MEDIA \& TEACHER's CAMPUS». This program was performed at Sumy State Pedagogical University named after A.S. Makarenko in cooperation with Horlivka Institute of Foreign Languages 
(Donbass State Pedagogical University) and All-Ukrainian Center for Vocabulary of the Ukrainian Lingua-Information Fund of the National Academy of Sciences of Ukraine in order to develop infomedia literacy of future tutor-teachers on the basis of academic integrity and interregional partnership. Within the framework of the Virtual Lexicographic Laboratory a «Multimedia Dictionary of Infomedia Literacy» was created as an active tool for interaction between compilers-participants of the project (scientists, teachers of various subjects, journalists, academics, students) from different settlements of Ukraine and abroad.

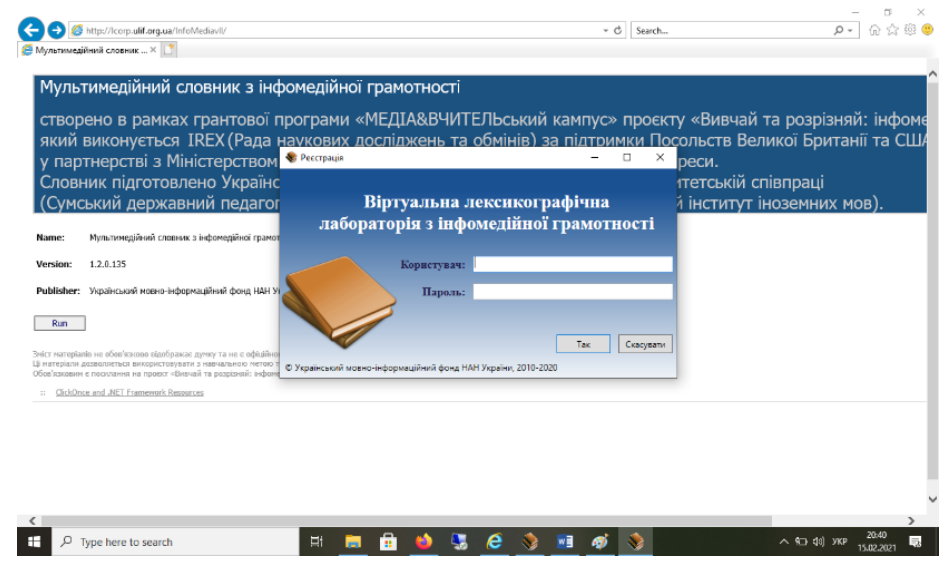
Fig. 1. - Entrance window to the Virtual Lexicographic Laboratory «Multimedia Dictionary of Infomedia Literacy». Access mode: https://lcorp.ulif.org.ua/InfoMediaVLL/

The dictionary formulates the basic concepts of the philological direction of knowledge, comprehensively presents the tools, methodology, methods and aspectology of scientific approaches important for media linguistics. Vocabulary articles include those related to the actual linguistic concepts, without which it is impossible to analyze the specifics of language in the media, which is a syncretic field of modern humanities (especially journalism, some political sciences etc.). The register of tokens is based on the concept of infomedia literacy, developed by the Council for International Research and Exchanges (IREX). The authors of this concept believe that the components of infomedia literacy are: медіаграмотність; критичне мислення; соиіальна толерантність; стійкість до впливів, перевірка фактів; інформаційна грамотність; цифрова безпека; візуальна грамотність; інноваційність, 64 
розвиток креативності. The dictionary provides Ukrainian equivalents to foreign words, for example, лід (lead) - вріз, врізка.

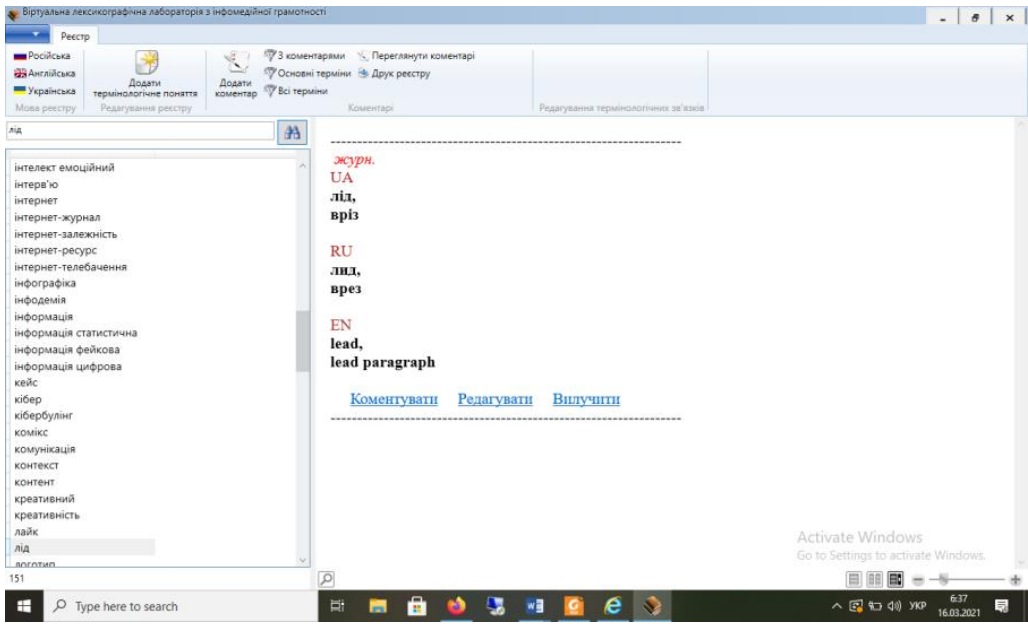

Fig. 2. - The token «лід (lead)» in the «Multimedia Dictionary of Infomedia Literacy»

The dictionary provides an interdisciplinary approach by introducing into the registry the main terms of textbooks that reveal the issues of medialiteracy education in science and biology, chemistry, geography etc. (https://www.aup.com.ua/posibnik-mediaosvita-v-shkoli- ta-na-uro /). The Virtual Laboratory «Multimedia Dictionary of Infomedia Literacy» offered to users is a tool for interaction between teachers (project participants) of different subjects and different settlements.

Currently, we are testing a multimedia dictionary on media literacy. The results will be announced at international scientific and practical conferences "Cultural personality of the specialist in the XXI century», "Academic culture of the researcher in the educational space: European and national experience».

\section{References:}

1. Hobbs R. The Seven Great Debates in the Media Literacy Movement. Journal of Communication, Volume 48, Issue 1, March 1998. P. 16-32.

2. Лінгвістично-інформаційні студії : праці Українського мовноінформаційного фонду НАН України : у 5 т. / В.А. Широков та ін. Т. 1 : Наукова парадигма та основні мовно-інформаційні структури. Київ. 
Український мовно-інформаційний фонд НАН України. 2018. 271 с. DOI 10.33190/978-966-02-8683-2/8684-9.

3. Академічна культура дослідника в освітньому просторі: європейський та національний досвід [Текст] : збірник матеріалів II Міжнародної науково-практичної конференції, (м. Суми, 16-17 травня 2019 року) / за ред. О. М. Семеног. - Суми : Видавництво СумДПУ імені А. С. Макаренка, 2019. - 220 с.

DOI https://doi.org/10.30525/978-9934-26-073-5-1-15

\section{РОМАН Т. ТОЛСТОЙ «КЫСЬ» В СВЕТЕ ЯЗЫКОВОЙ ИГРЫ}

\section{Сербина Т. Г.}

кандидат филологических наук, доиент, доиент кафедры теории и истории мировой литературы Ривненского государственного гуманитарного университета 2. Ровно, Украина

\section{Чеберяк А. Н.}

кандидат филологических наук, доцент, дочент кафедры романно-германской филологии Ривненского государственного гуманитарного университета г. Ровно, Украина

Ведущими принципами языкового построения постмодернистского текста провозглашаются деструктивизм, абсурдизм и развенчание стереотипов. Формальным приемом реализации этих принципов становится языковая игра (ЯИ).

Большинство исследователей $[1,2,3]$ видят в ЯИ намеренное речетворчество автора, основанное на отступлении от любой языковой нормы «для создания остроумных высказываний, в том числе комического характера» $[4$, с.79]. Иллюстрацией умелого использования языковой игры в художественном тексте служит роман «Кысь» Татьяны Толстой.

Толстая называет свой роман лингвистической утопией, что проявляется в экзотичности ее языка. В романе придумана флора и фауна, множество реалий, для названия которых она использовала окказиональное словообразование. В частности, растут там ржавь и хлебеда, хвощ и огнецы, в лесу живут кысь, слеповран и древяница, едят 66 